\title{
The Echinoderms collected by the "Huxley" from the North Side of the Bay of Biscay in August, 1906.
}

By

\author{
W. De Morgan.
}

Mr thanks are due to Dr. Allen for permitting me to examine this collection.

In all 292 specimens were obtained, but of these 16 were young immature Asteroidea and Echinoidea. It is impossible to identify these with any degree of certainty, and I have not hazarded an opinion about them.

The remainder belong to 17 genera and 24 species. The Ophiuroidea were particularly numerous, 190 specimens belonging to that class.

The classification followed is that of Professor MacBride in the Cambridge Natural History.

\section{ASTEROIDEA.}

\section{FAM. ASTERINID床.}

Palmipes placenta (Pennant).

Station V. One specimen. 109 fathoms.

Bottom coarse sand and shells.

\section{FAM. PENTAGONASTERID压.}

\section{Dorigona subspinosa (Perrier).}

Pentagonaster subspinosus. E. Perrier. Bull. Mus. Comp. Zoology, Vol. IX, No. 1, p. 21.1881.

Pentagonaster subspinosus. E. Perrier. Nouv. Arch. du Mus. d'Histoire Naturelle, t. VI, p. 234. Pl. VI, Fig. 1. 1884.

Nymphaster protentus. Sladen. Challenger Reports, Vol. XXX, p. 203. Pl. L, Figs. 3 and 4. Pl. LIII, Figs. 9 and 10.1889.

Nymphaster subspinosus. Bell. Catalogue of British Echinoderms in British Museum, p. 75. 1892.

Nymphaster subspinosus. Norman in Bourne. Journal Marine Biological Association, Vol. I, p. 327. 1890. 
Dorigona subspinosa. E. Perrier. Travailleur et Talisman. Echinoderms, p. 375. 1896.

Station XIII. One specimen. 412 fathoms.

A fine specimen. $R=102 \mathrm{~mm} ., \mathrm{r}=25 \mathrm{~mm}$. Breadth at base of arm $16 \mathrm{~mm}$. Very few pedicellariæ. Colour in alcohol, light biscuitbrown.

\section{FAM. ASTERIID压.}

Asterias rubens, Linnæus.

Station II. One specimen. 75 fathoms.

\section{OPHIUROIDEA.}

\section{FAM. OPHIOLEPIDID不.}

Ophiura ciliaris, Linn.

Station V. 109 fathoms. 60 specimens.

Station IX. 240 fathoms. 6 specimens.

Station XII. 246 fathoms. 3 specimens.

The specimens dredged from Stations IX and XII are small, the largest having a disc only $5 \mathrm{~mm}$. in diameter. They are remarkable for the thick cushion-like appearance of the discs, which were very convex above, and $2 \frac{1}{2}$ to $3 \mathrm{~mm}$. thick. This may be due to their removal from a considerable depth.

Ophiura albida, Forbes.

Station I. 75 fathoms. 1 specimen.

Station II. 75 fathoms. 1 specimen.

Station V. 109 fathoms. 1 specimen.

Ophiura affinis, Lütken, 1859.

Ophiura Grubei. Heller. SB. AK. Wien, XLVI, p. 431. Pl. II, Figs. 13-16. 1863.

Ophiura Normani. Hodge. Trans. Tynes. Nat. Field Club, V, p. 296. Pl. XVI. 1863.

Ophioglypha affinis. Lyman. Ill. Cat. Mus. C.Z., I, p. 52. 1865.

Ophioglypha affinis. Lyman. Chall. Rep. Oph., p. 77. 1882.

Ophiuraaffinis. Bell. Brit. Mus. Cat., p. 111. 1892. 


$\begin{array}{lrrr}\text { Station } & \text { I. } & 75 \text { fathoms. } & 1 \text { specimen. } \\ \text { Station } & \text { II. } & 75 \text { fathoms. } & 15 \text { specimens. } \\ \text { Station } & \text { V. } & 109 \text { fathoms. } & 14 \text { specimens. } \\ \text { Station XI. } & 146 \text { fathoms. } & 4 \text { specimens. } \\ \text { Station XII. } & 246 \text { fathoms. } & 2 \text { specimens. }\end{array}$

The diameters of the dises measured dry were as follows :-

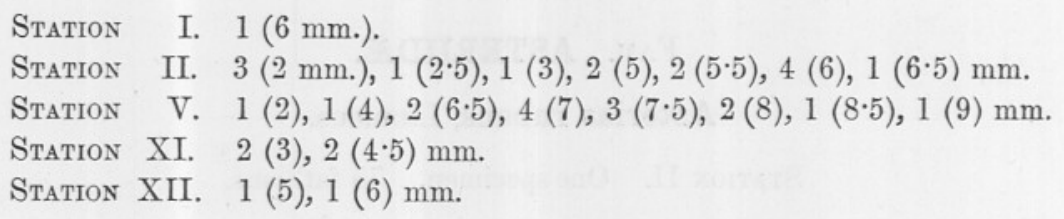

One specimen is recorded from Plymouth (Journal M.B.A., Vol. V, N.S., 1897-9). This was from Bolt Head shell gravel ground. It agrees in all respects with the Huxley specimens. Diameter of disc, $4.5 \mathrm{~mm}$.

Four specimens were also obtained from a collection made in the English Channel by Mr. Crawshay, at Station V, 20 miles S. $19^{\circ} \mathrm{W}$. of the Eddystone (Jour. Mar. Bio. Assoc., IX, p. 336). The dises of these measure $7,6,6$, and $3.5 \mathrm{~mm}$. in diameter, and in other respects they are similar to the Huxley specimens.

In all the above specimens the number of lateral spines is constant, namely three. The uppermost spine is the longest, and reaches halfway up the next dorsal plate of the ray. This exactly agrees with Lütken's description. Heller also states that there are three lateral spines.

Hodge (5), however, states that there are five lateral spines, and Jeffrey Bell (1) " about five."

Jeffrey Bell (1) describes as a "very small species."

Hodge (5) says that the disc "in well-grown individuals measures about $\frac{1}{4}$ inch."

Lütken says that it is 5 to $6 \mathrm{~mm}$. in diameter.

The Huxley specimens show that it grows to a much larger size. The largest dried specimen from Station V, 109 fathoms, was $9 \mathrm{~mm}$. diameter.

In descriptions of Ophiura affinis emphasis is laid on the regular rosulation of the primary plates. Judging from the Huxley specimens this is true only of the smaller and presumably younger individuals. In these there is a distinct rosette, consisting of a central and five surrounding plates, separated by smaller scales. As the animals increase in size the arrangement of the plates is not so regular, and they 
increase in number. Generally, however, indications of the primary arrangement may be traced.

The arm combs have a variable number of spines. In some specimens there were twelve on each side. On each side of the notch there are a variable number of small spinules, sometimes six on each side; and in the centre of the notch a small cluster. There may be a variable number of spines on the first upper arm-plate. Occasionally there is a complete row on each side of the arm-plate, which in continuation with those on the sides and centre of the notch form a complete curve of spinules. The arrangement is very variable, but the notch and arm-plate never appear to be quite destitute of spines.

In the Huxley collection, and other spirit-preserved specimens examined, the arms are banded at regular intervals with a darker shade.

\section{Ophioconis Forbesi (Heller).}

Station V. 109 fathoms. 1 specimen.

The disc is rather distorted, but the diameter would be about $6 \mathrm{~mm}$. Ophioconis Forbesi is described as Pectinura Forbesi by Heller in Untersuchungen iiber die Litoralfauna des adriatischen Meeres. Kaiserlischen Akad. der Wissenschaften. 1862. Vol. XLVI, p. 423. Pl. II, Figs. 5-8.

See also Lütken, Additamenta ad historiam Ophiuridarum, Part III, p. 98.1869 .

\section{AMPHIURID尔.}

Amphiura elegans (Leach).

Station I. 75 fathoms. 5 specimens.

Station V. 109 fathoms. 6 specimens.

Ophiactis Balli (Thompson).

Station I. $\quad 75$ fathoms. 1 specimen.

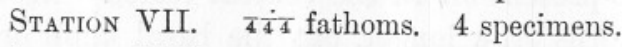

Station XIII. 412 fathoms. 6 specimens.

\section{Ophiactis abyssicola (Sars).}

Amphiura abyssicola. Sars. Norg. Ech. (1361), p. 18. Pl. II, Figs. 7-12.

Ophiocnida abyssicola. Lyman. Ill. Cat. Mus. C.Z., I. 1865, p. 12.

Ophiactisabyssicola. Bell. Brit. Mus. Cat. Echinoderms, p. 123. 


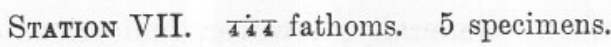

Bell describes it as a rather small species. The two largest Huxley dried specimens have a disc diameter about $5 \mathrm{~mm}$.

It is at once distinguishable from Ophiactis Balli by the unequal thickened disc scales and spines, and the large radial plates.

Ophiacantha abyssicola, G. O. Sars.

Station XII. 246 fathoms. 17 specimens.

Station XIII. 412 fathoms. 3 specimens.

All are young animals. The largest has a disc $5.5 \mathrm{~mm}$. diameter, and arm $20 \mathrm{~mm}$. long, as nearly as could be measured on a dry specimen. Bell (1) describes abyssicola as " a small species."

Diameter of disc $9 \mathrm{~mm}$., and $\mathrm{R}$ said to $=10 \mathrm{r}$. 0 . abyssicola has been obtained by the Travailleur et Talisman Expedition (6), p. 288, between Lat. N. $35^{\circ} 42^{\prime}$, Long. W. $8^{\circ} 40^{\prime}$, and Lat. N. $44^{\circ} 5^{\prime}$, Long. W. $9^{\circ} 25^{\prime} 40^{\prime \prime}$ in depths from 112 to 1226 metres, and by the Caudan Expedition between Lat. $45^{\circ} 57^{\prime}$, Long. $6^{\circ} 41^{\prime}$, and Lat. $46^{\circ} 40^{\prime}$, Long. $6^{\circ} 58^{\prime}$ in 400 to 1700 metres. Koehler remarks (6) that all these specimens are identical with those from the coasts of Norway.

Bell (1) makes the translucency of the arm spines the key of the species, and this characteristic and the moniliform appearance of the arms is very marked in the Huxley specimens.

Grieg (3) remarks that 0 . abyssicola seems to be subject to sundry small variations as regards the spines on the disc, the aculeation of the branchial spikes, and their number, which is variable, and should not, in his opinion, be regarded as specifically diagnostic.

The spinulation of these young specimens is worthy of note. Both the dorsal and ventral surfaces of the disc are covered with thin subcircular imbricated scales. All the dorsal scales bear a knob or granule crowned with two to six very fine thorns. These thorny knobs are not present on all the ventral scales. As the disc increases in size the thorns grow longer, but the basal knob or granule remains about the same size. As the disc increases in size the thorns appear to coalesce into a single longer aculeated spine. This spine is much constricted at the proximal end, and easily breaks off from the knob. In the adult probably all the longer spines ultimately break off, leaving the disc covered with knobs or granules, as figured by Grieg. I have observed similar changes in Ophiactis Balli, and they are probably common to other Ophiurids. 


\section{Ophiacantha bidentata, Retzius.}

Asterias bidentata. Retzius, 1805.

Ophiura Retzii. Nilsson, 1817.

Ophiocoma arctica. M. Troj. Syst. Ast., 1842.

Ophiocoma echinulata. Forbes, 1852.

Ophiacantha Gronlandica. M. Tr. Arch.f. Nat., 1844.

Ophiacantha spinulosa. Sars, Norg. Ech., 1861.

Ophiacantha spinulosa. Lyman, Ill. Cat. Mus. C.Z., I., 1865, p. 93 and figure.

Ophiacantha bidentata. Jeffrey Bell, Cat. Brit. Mus., p. 127.

Station VII. $\frac{\dot{4+4}}{44}$ fathoms. 9 specimens.

Station X. 146 fathoms. 10 specimens.

O. bidentata was taken by the Talisman et Travailleur Expedition between Lat. $19^{\circ} 19^{\prime}$, Long. $20^{\circ} 20^{\prime}$, and Lat. $39^{\circ} 33^{\prime}$, Long. $12^{\circ} 11^{\prime} 30^{\prime \prime}$ in depths from 1965 to 2590 metres. All the specimens were small, the largest not more than $9 \mathrm{~mm}$. diameter.

It was found by the Caudan Expedition in Lat. $45^{\circ} 47^{\prime}$, Long. $6^{\circ} 15^{\prime}$ in 17 metres.

The largest of the Huxley specimens has a disc diameter of only $5.5 \mathrm{~mm}$., and the others are considerably smaller. Bell (1) gives the disc diameter as $13 \mathrm{~mm}$. The Huxley specimens are therefore probably all young and immature. Descriptions of the species vary in certain points.

Bell (1) describes the mouth papillæ as "not numerous," but inconstant in number, and to some extent in position, as is the mouth shield in form. The disc covered with very short spines.

Lyman (8) gives 0 . spinulosa as the type of the genus, as its special mark "Disc evenly covered with short spines." The mouth papillæ, however, he describes as "standing well apart; six or seven to each angle of the mouth-two outermost on each side small, flattened, somewhat rounded, blunt; innermost one sharp, conical, rounded, resembling the lowest tooth, which also might be well enough considered as a mouth papilla. Teeth seven." The Huxley specimens agree in all these points, except that there are only four teeth. This might be accounted for by their age.

Lütken (7) describes and figures O. bidentata. The Huxley specimens agree with the figure, except in the magnified appearance of the spines. In the Huxley specimens the dorsal and ventral faces of the disc are covered with short, smooth, cylindrical spines, in some cases bifurcated. They stand on a slightly thorny stump or grain. 
The plane of junction between the stump and the cylindrical spine is constricted, so that the spine might easily be brushed off the grain, as in the case of $O$. abyssicola. There is no indication of scales on the disc as in 0 . abyssicola, and the spines are equally thick on the ventral and dorsal surfaces.

Considering the immaturity of the specimens, and the variability of spinulation in young ophiurids, it would be rash to finally diagnose these as 0 . bidentata, but their general appearance makes it probable that they belong to that species.

\section{OPHIOCOMID压.}

Ophiocoma nigra, O. F. Müller.

Station VII. $\frac{\dot{4} 4}{44}$ fathoms. 18 specimens.

\section{ECHINOIDEA.}

Cidaridæ.

Cidaris papillata (Leske), 1778.

Station XI. 146 fathoms. 17 specimens.

Station XII. 246 fathoms. 14 specimens.

Station XIII. 412 fathoms. 19 specimens.

\section{ECHINOTHURIID压.}

Phormosoma luculentum, Agassiz.

Station XII. 246 fathoms. 1 specimen.

Station XIII. 412 fathoms. 3 specimens.

This species is described and figured by A. Agassiz in his report on the Echinoidea. The voyage of H.M.S. Challenger, Vol. III, p. 97, Pls. IX, X, $\mathrm{X}_{\mathrm{A}}$, Figs. 3-7; Pl. XXXIX, Fig. 8; Pl. XL, Figs. $31-36$; Pl. XLIV, Figs. 25-27.

It was obtained by the Caudan Expedition (6a), and in the N. Atlantic by the Hirondelle.

\section{ECHINID㡺.}

Echinus norvegicus, Düb. o. Kor, 1844.

Station V. 109 fathoms. 1 specimen.

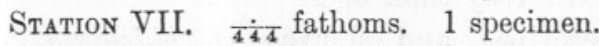

Station XII. 246 fathoms. 3 specimens.

These are young animals. The measurements of the largest taken at Station XII are: Diameter of test, $13.5 \mathrm{~mm}$; height of test, $7.5 \mathrm{~mm}$.; length of longest spine, $13 \mathrm{~mm}$. 
Although collected three years ago, preserved in spirit, and dried, the red patches on the test are quite clear in the larger specimens.

\section{CLYPEASTROIDEA.}

Fibularidæ.

Echinocyamus pusillus, O. F. Müller.

Station XII. 246 fathoms. 2 specimens.

\section{SPATANGOIDEA.}

\section{Spatangidæ.}

Spatangus purpureus (O. F. Müller).

Station II.

2 specimens.

Station XII. 246 fathoms. 2 specimens.

\section{Spatangus Raschi (Loven).}

Station IX. 240 fathoms. 30 specimens.

Echinocardium pennatifidum, Norman.

Station XI. 146 fathoms. 4 specimens.

\section{HOLOTHUROIDEA.}

\section{ASPIDOCHIROTA.}

\section{FAM. HOLOTHURIIDE.}

Stichopus tremulus. Gunnerus (Östergren).

Stichopus Richardi. Hérouard.

Stichopus Richardi. R. Perrier.

Holothuria tremula. Gunnerus. 1767. Düben and Koren, Sars, Théel, Jeffrey Bell.

Holothuria elegans. F. O. Müller, Jäger, Brandt.

\section{Station IX. 240 fathoms. 7 specimens.}

Station XII. 246 fathoms. 1 specimen.

Up to 1896 this species was regarded as a true Holothurian, possessing only one bundle of genital tubes. In 1896, Östergren (9) demonstrated that it has two bundles of genital tubes, and consequently, as a true Stichopus, should be called Stichopus tremulus.

R. Perrier, in his examination of the Holothurians of the Talisman 
et Travailleur Expedition, also recognized the two bundles of genital tubes (10), p. 485, and included his specimens in the genus Stichopus.

Hérouard (4), p. 8, described what he thought to be a new species under the name of Stichopus Richardi. R. Perrier (11) called attention to the resemblance between this new species and Holothuria tremula, and also how it differed in the arrangement of the ambulacra, and in possessing two bundles of genital tubes. Perrier then read Östergren's work, and concluded that Stichopus Richardi and Stichopus tremulus are identical.

He then made certain additions to Östergren's description, and gives figures of the sclerites. Hérouard (4), Pl. VIII, gives drawings of the sclerites of Stichopus Richardi which agree with Perrier's. He, however, does not figure the "spire" (or "tige," as Perrier has it) of the disc, which is very characteristic.

The Huxley specimens agree with Perrier's description of Stichopus tremulus in external form, in the shape of the sclerites, and in possessing two bundles of genital tubes, one on each side of the dorsal mesentery. Both Théel (12) and Jeffrey Bell (1) make the absence of C-shaped deposits characteristic of Holothuria. Perrier describes arciform spicules in the ambulacral papillæ, and in the ventral feet of Stichopus tremulus, and such arciform spicules appear in the Huxley specimens, some being sufficiently curved to warrant the description C spicules.

These specimens have been some years in spirit, but in places a faint rosy tinge is still discernible.

\section{Stichopus regalis (Cuvier).}

Holothuria columnce. Cuvier. 1817.

Holothuria triquetra. Della Chiaje. 1828.

Station XI. 146 fathoms. 1 specimen.

Stichopus regalis is easily recognized by the flattened ventral surface, and the well-marked division between that and the slightly convex dorsal surface. The dises of the tables also are very characteristic. They have a fairly unbroken margin, and want the sharp marginal teeth found in Stichopis tremulus. They are perforated by numerous holes, Théel (12).

Perrier's (11) description is very similar. He states that in young specimens the four rods are longer in proportion to the diameter of the basal disc, and are more convergent at the top. Also that in young specimens, the four rods are smooth, and end in a point, while "chez les 
adults elles sont hérisées de dents à leur extremité et aussi sur une certaine longueur au-dessous de cette extremité."

In the Huxley specimen some of the discs have 54 perforations, the average being about 44 .

This specimen, which has been three years in spirit, still gives a very fair notion of the colour as described by Perrier.

\section{CRINOIDEA.}

\section{Comatulidæ.}

Antedon bifida (Pennant $=$ rosacea).

Station V. 109 fathoms. 2 specimens.

Antedon flava, Koehler.

Station XIII. 412 fathoms. 2 specimens.

I am indebted to Dr. Koehler, of Lyons, for identifying this species.

Two specimens were obtained by the Caudan Expedition from a depth of 1410 metres, and it is described and figured (6a), p. 9, Figs. 20 and 21.

Actinometra pulchella. Pourtalès.

Antedon alata. Pourtalès, Bull. Mus. C.Z., 1878, Vol. V, No. 9, 215. Antedon pulchella. Pourtalès, ib., 216.

Actinometra pulchella. 1881. P. H. Carpenter, ib., Vol. IX, 4, p. 10. Actinometra pulchella. 1888. P. H. Carpenter, Challenger Reports, Vol. XXVI, p. 304, Pl. IV., LII.

Actinometra pulchella. 1896. Koehler, Campagne du Caudan, p. 100 .

Station VII. $\frac{\dot{4 i 4}}{44 h o m s . ~} 2$ imperfect specimens.

Station XIII. 412 fathoms. 15 specimens, of which two are good, the others badly mutilated.

This species was obtained by the Blake [Carpenter (2)], at a great number of stations, but at depths nowhere over 300 fathoms and rarely exceeding 200 fathoms. The Porcupine specimens were dredged at 477 fathoms and those of the Dacia at 533 fathoms. The Caudan specimens were from depths varying from 400 to 1710 metres.

Except two species of Rhizocrinus, this is the only Crinoid common to the European and Caribbean seas, and the only European species of Actinometra. 
LIST OF SPECIES AND STATIONS AT WHICH THEY OCCURRED.

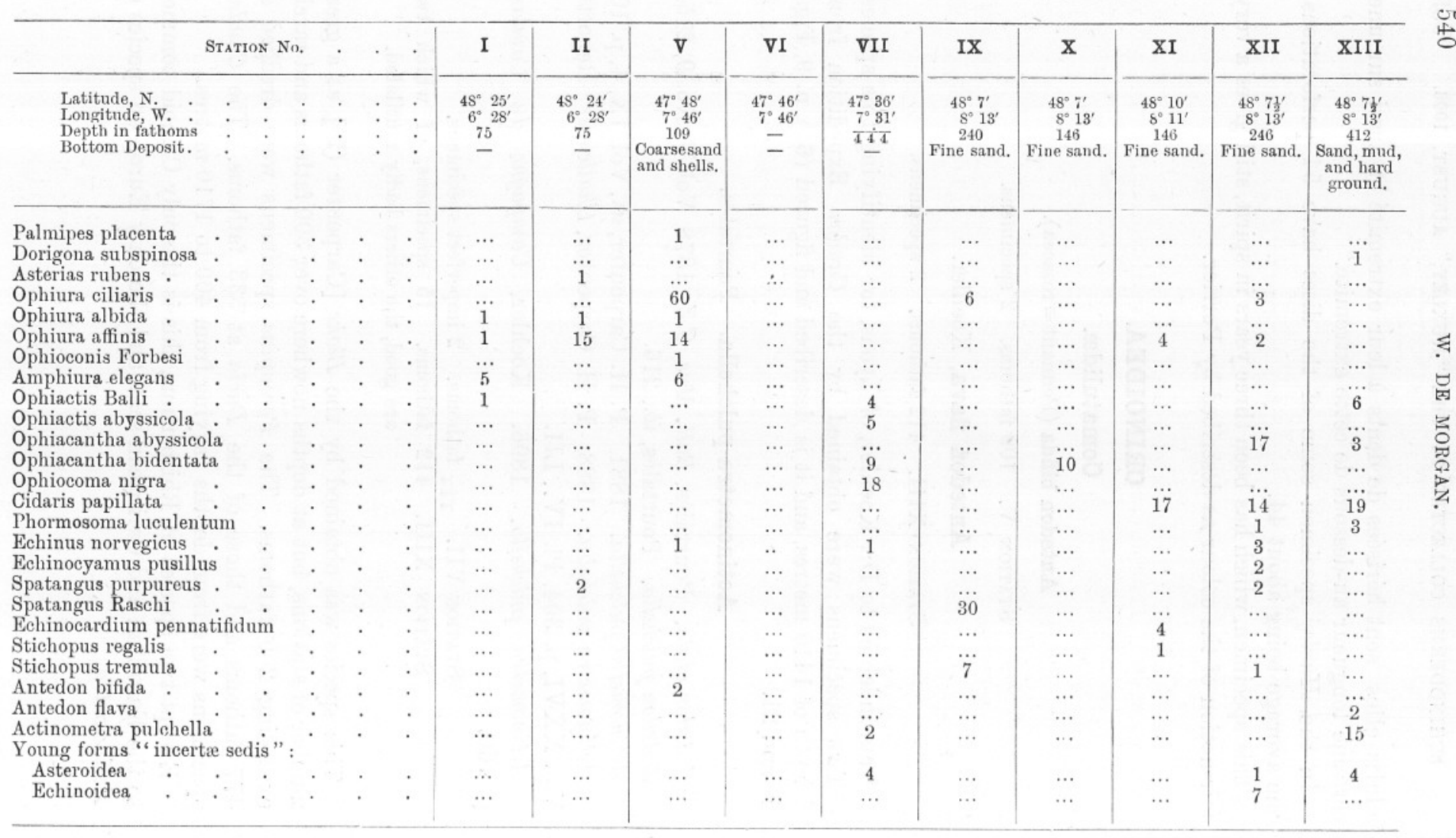




\section{BIBLIOGRAPHY.}

1. Bell, F. Jeffrey. Catalogue of the Echinoderms in the British Museum. (Nat. Hist.)

2. Carpenter, P. H. Proceedings of the Royal Society of Edinburgh. $1883,4$.

3. Grieg, James A. The Norwegian North Atlantic Expedition. 1876-8. Ophiuroidea.

4. Hérovard. Les resultats des campagnes scientifiques. Monaco, t. XXI.

5. Hodge. Transactions of the Tyneside Naturalists Field Club, V, 1863.

6. Koenler, R. Expéditions scientifiques du Travailleur et du Talisman pendant 1880-83. Ophiures.

6a. Koenler, R. Campagne du Caudan. 1896.

7. Lütken, Chr. Fr. Additamenta ad historiam Ophiuridarum. Part III.

8. Lyman, Theodore. Ill. Cat. of Museum Comp. Zoology at Harvard. No. 1. Ophiuridae.

9. Östergren, HJalmar. Ueber die Holothurien Norwegens. Bergens Museums Aarbog. 1896. No. 12.

10. Perrier, R. Expéditions scientifiques du Travailleur et du Talisman. 1880-3. Holothuries.

11. Perrier, R. Sur les Holothuries draguées par le Travailleur et Talisman.

C. R. de l'Acad. des Sciences, t. CXXVI, p. 1664.

12. ThéEL. Report on the Holothuria of Challenger Expedition. 